\title{
Language learning strategies among less proficient learners in Oman
}

\author{
${ }^{1}$ Anita Teresa Boggu, Dr.J. Sundarsingh ${ }^{2}$ \\ I'Department of English, Majan College (University College), Sultanate of Oman) \\ ${ }^{2}$ (Department of English, Karunya University, Coimbatore)
}

\begin{abstract}
The present study examined the most frequently used language learning strategies among the less proficient learners. In addition to exploring the influence of age and gender on LLS, it also attempted to analyze the impact of full-time work experience on the language strategy use of part-time learners .Convenience sampling technique was used to carry out the survey involving 82 students from Majan College belonging to Level 0(i.e. Foundation) and Level-1(i.e. Undergraduate). The Strategy Inventory for Language Learning for learners of English as a foreign language was implemented for this purpose. The results of this study indicated that the less proficient learners used compensation and memory strategies more frequently than cognitive, metacognitive, social and affective strategies. Age and gender had no significant effect on the frequency of strategy use. However part time students who had an advantage of working experience, displayed a higher strategy use than the full time students with a significant difference..
\end{abstract}

Keywords: full time students, part-time students, age, gender, less proficient language learners, language strategies,

\section{Introduction}

A substantial amount of research has been conducted on the language learning strategies of Arabic speakers in several Middle East countries, but Oman has very limited research in this area, except for Radwan, (2011) who explored the impact of gender and language proficiency of Omani graduates on language strategy use. Hence, there is a need to explore the impact of various learner variables that impact the learning strategies of Omani students. In Oman, English is taught as a foreign language from grade one onwards. Graduates who successfully pass the General Education Diploma Certificate enroll in government and private colleges for various academic courses. The students, who score below the cut-off percentage required by the government institutions, are left with no other choice than to join private colleges. Most of the low proficient learners seek private colleges that have no entry or placement tests for admissions. It should be noted here that Omani school students have encountered English as a foreign language rather than second language, attending an English lesson for approximately forty-five minutes every day.The shift from an Arabic medium of instruction with English as a foreign language to an environment of English as the medium of instruction is not a smooth transition to most of the students. This shift strikes a chord of uneasiness among students, specifically the unsuccessful learners. To bridge the gap and equip students with the language skills required, tertiary institutions run Foundation Programmes. According to the Ministry of Higher Education, Oman (Ministerial Decision No.72/2008), a foundation course prepares students for their post-secondary and higher education studies.

A surge for post-secondary education for adults seeking jobs in the government and private sectors had led to an increase in part-time enrollments in educational institutions. In recent years, it has been observed that there is an influx of employed adults registering for various vocational and technical courses due to vast career enhancement opportunities. Exploration on educational trends, gave rise to a new term, 'traditional and nontraditional student'. Students who enroll in higher education institutions directly after graduating from high school are the traditional students(full-time), whereas the term 'non-traditional'is elaborately defined by the National Center for Education Statistics(2002) as 'a student who meets one of the seven characteristics: delayed enrollment into postsecondary education; attends college part-time; works full time; is financially independent for financial aid purposes; has dependents other than a spouse; is single parent; or does not have a high school diploma'. It is overwhelming to note that nontraditional students make up 73 percent of the total enrollments in undergraduate programmes according to a report by the US National Center for Education Statistics (NCES, 2002). It has been recorded that there is a disagreement with the terms 'traditional' and 'non-traditional' in various studies in myriad contexts, hence students in this study will be referred to as full time and part-time learners.

Although there are studies that investigated the academic success of non-traditional students, there is a very limited body of research on the students' part-time work experience.An insight into the learner variables 
such as low proficiency, age, gender and the work experience could educate the instructor on how to equip the learner with successful learning strategies to overcome their weaknesses and develop successful learning strategies.

The objective of this research was to determine the type of strategies most frequently used by the unsuccessful or less proficient students which include both full time and part-time students. For the purpose of this study 82 students from Majan University College participated. The samples selected were part of a remedial teaching class consisting of low achievers in English.

\section{Literature Review}

The central focus of the most significant discussions in the field of ELT revolves around the 'Learner'. Over the past decades, the focus has been shifted from the teacher-centred approach of teaching to 'learner centered approach. This approach also gained importance at the higher education level.It positions the instructors as facilitators rather than givers of information (Blumberg, P. 2008). With learners being at the core of the teaching-learning process, it is imperative for educators to ponder on the effectiveness of the curriculum in order to incorporate strategies to develop 'successful learners'. As identified by Oxford (1990), O'Malley and Chamot (1990, the successful learner in L2 are the ones who adopt various learning strategies or methods consciously, to cope up with their learning problems. While a successful learner is a delight to teach, an unsuccessful learner could be a disappointment to some instructors. A very interesting question posed by Mary Ann Reiss (1981) was, 'Can our knowledge of the successful language learner aid the unsuccessful language learner?' Cohen and Weaver (1998) remind us that, 'Second language learner strategies encompass both second language learner and second language use strategies'. Both elements, learner and learning strategies play an important role in creating a successful learner.

Learning strategies' is a commonly used term, yet it is a concept that is difficult to define. The most prominent studies that defined this term three decades or more is that of Rubin (1975). According to Rubin (1975), learning strategies are defined as 'the techniques or devices which a learner may use to acquire knowledge'. While a variety of definitions emerged to date, the most influential definition that was adopted by many researchers on learning strategies was that of Oxford (1990b) stated that,' foreign or second language (L2) learning strategies are specific actions, behaviors, steps, or techniques students use often consciously to improve their progress in apprehending, internalizing, and using the L2'.

\subsection{Related studies in Language Learning Strategies}

A large and growing body of literature has investigated learner variables such as age, gender, learning styles, motivation and cultural backgrounds on the effect of learning strategies. In the Middle-East, numerous studies have been carried out on Arabic learners. Although all these studies involved Arabic speakers, it is interesting to note the fluctuation of the effect of leaner variables on strategy use. Radwan (2011) surveyed 128 students at a college in Oman, to examine the relationship between gender and English proficiency. He concluded that there was no significant difference on the use of language strategies by both genders, parallel to surveys conducted by (Ali Erarslan 2014, SalimRazi 2012,Abu Shamis 2003).On the contrary, a variation was observed between Omani and Palestinian students influence of proficiency on learning strategies.Radwan ( 2011) deduced from the findings that language proficiency had a significant effect on the overall strategy use while Abu Shamis (2003) noted no significant difference of proficiency on language strategies .

Extensive studies have been conducted in learning strategies till date but, there is still an inadequate research on identifying the effect of working experience of learners on the selection of learning strategies, particularly in the Arab world. The relationship between language learning experiences and strategy use was observed in three studies. A few studies on Arabic learners investigated the experience of educational background and learner strategy. According to Razi(2012), there was no significant difference between learners with less or more than ten years of English language learning experience with regards to strategy use. Uztosun (2014) introduced the language learners' educational background as one of the learner variables. Based on educational background of learners, he revealed that the more experienced learner displayed a wider range of strategy use than the less experienced learners. There was a disconnection noticed between language learning experience and strategy use in the study carried out by Hiçyilmaz (2006)( as cited by Uztosun 2012).

In addition to the formal learning experiences, informal experiences of the learner form an essential area of study to gain awareness of the influence on learning strategies. This effect is specifically noticeable in the case of the part-time students, who are increasing at an alarming rate. A large intake of part-time students has been recorded at the tertiary level. (NCES, 2002)

Knowles (1980) claims that learning becomes more meaningful to mature learners when it is combined with the learners prior experiences. This study attempts to distinguish the young adults from the older adults to observe the effect of age, gender and working experience on language learning strategies. 


\subsection{Research Questions}

\section{Research Methodology}

In order to understand the frequency of language learning strategies among the less proficient learners the following research questions were projected.

1. What are the most preferred learning strategies employed by the less proficient students?

2. Does age influence the use of learning strategies?

3. How do males and females differ in their use of learning strategies?

4. Are there differences in frequency of learning strategies between the full-time and part-time students?

\subsection{Respondents Profile}

The participants of this study comprised of 45 full time students and 37 part-time students, totaling to 82 .The respondents were exclusively native Arabic speakers. $55 \%$ of respondents were under the age of 25 and $45 \%$ above 25 years old. In the current survey, students below 25 years of age would be termed as 'young adults' and those above 25 years of age, 'older adults'. The total population for this investigation was taken from Majan College, (35) Foundation students and (47) Undergraduate students.

Table.1 Distribution of participants according to age, gender and level.

\begin{tabular}{|l|l|l|l|l|l|l|}
\hline Mode of study & Participants & \multirow{2}{*}{ Age } & \multicolumn{2}{|c|}{ Gender } & Level & Foundation \\
\cline { 3 - 6 } & & & M & F & UG \\
\hline Full Time & 45 & $<25$ & $12(27 \%)$ & $33(73 \%)$ & $35(78 \%)$ & $10(22 \%)$ \\
\hline Part-time & 37 & $>25$ & $21(57 \%)$ & $16(43 \%)$ & & $37(100 \%)$ \\
\hline Total & 82 & & $33(40 \%)$ & $49(60 \%)$ & $35(43 \%)$ & $47(57 \%)$ \\
\hline
\end{tabular}

\subsection{Method}

To assess language learning strategies, the Strategy Inventory for Language Learning devised by Rebecca Oxford (1990) was used for collecting data on the strategies employed by the non-native speakers. The questionnaire contained demographic information about the learners and the SILL consisting of 50 items. An Arabic version of the SILL designed by Abu Shmais, W. (2003) was used to measure the strategy use.

SILL has been considered the most reliable and influential tool, specifically useful with large sample size (Chamot 2005).SILL contains categories namely; memory, cognitive, compensation, metacognitive, affective, and social strategies. The SILL adopts a 5 point Likert scale item, with options ranging from never to almost always. The six learning strategies are classified into direct and indirect strategies. The direct strategies include memory, cognitive and compensation strategies which basically focus on information that is stored in the memory, retrieval of information, associating the data with new facts and bridging the gap intelligently by guessing the unknown information.

The indirect strategies include the metacognitive, affective and social strategies. These strategies are assumed indirect since they act as a backup of knowledge, supporting the direct strategies. These strategies enable a learner to organize and reflect on their learning, find ways to develop their potential by encouraging their inherent skills and utilizing their social surroundings to enhance their learning.

English instructors supervised the completion of the SILL during their regular class timings. The Arabic version of SILL was used since we were dealing with less proficient learners who were weak in English. The questionnaire was completed within 20 minutes. The demographic information included a checklist of age, gender and mode of study. The part-time students belonged to the class taught by the researcher; hence information regarding working experience was confirmed through student's registration records.

\section{Findings}

Table 2: The data collected was interpreted using the scoring scale given in Oxford (1990)SILL.

\begin{tabular}{|l|l|l|}
\hline \multirow{2}{*}{ High } & Always or almost always used & 4.5 to 5.0 \\
\cline { 2 - 3 } & Usually used & 3.5 to 4.4 \\
\hline Medium & sometimes used & 2.5 to 3.4 \\
\hline \multirow{2}{*}{ Low } & generally not used & 1.5 to 2.4 \\
\cline { 2 - 3 } & Never or almost never used & 1.0 to 1.4 \\
\hline
\end{tabular}

Oxford (1990)

Table 3: Overall strategy use

\begin{tabular}{|l|l|l|l|l|l|l|}
\hline \multicolumn{6}{|l|}{ Total number of participants $=82$} \\
\hline Strategy & MEM & COG & COMP & MCOG & AFF & SOC \\
\hline Mean & 1.90 & 1.87 & 2.00 & 1.65 & 1.87 & 1.81 \\
\hline SD & 0.49 & 0.47 & 0.55 & 0.49 & 0.63 & 0.71 \\
\hline
\end{tabular}

$\mathrm{MEM}=$ memory, COG-cognitive, COMP-compensation, $\mathrm{MCOG}=$ metacognitive, AFF-affective, SOC=social 
In order to answer the first question, 'What are the most preferred learning strategies employed by the less proficient students', a total number of 82 students questionnaires were analyzed. Table 3 indicates that the less proficient learners are low strategy users according to the scoring criteria. The most frequently used strategies were the compensation strategies $(m e a n=2.00)$ and the memory strategies (mean=1.90). An equal strategy use was noticed between cognitive (mean=1.87) and affective strategies (mean=1.87), followed by social strategies $($ mean=1.81) and the strategy that has never or almost never used was the metacognitive strategy (mean 1.65).

Table 4: Effect of age on learning strategies

\begin{tabular}{|c|c|c|c|c|c|c|}
\hline \multirow[t]{2}{*}{ Strategy } & \multicolumn{2}{|c|}{$<25$ (young adults) } & \multirow[t]{2}{*}{ Strategy } & \multicolumn{2}{|c|}{$>25$ (older adults) } & \multirow[t]{2}{*}{ t-test } \\
\hline & mean & $\mathrm{sd}$ & & mean & $\mathrm{sd}$ & \\
\hline COMP & 2.03 & 0.58 & MEM & 2.06 & 0.44 & \multirow{6}{*}{$\mathrm{t}=0.393$} \\
\hline SOC & 1.90 & 0.69 & AFF & 1.92 & 0.62 & \\
\hline $\mathrm{COG}$ & 1.87 & 0.49 & $\mathrm{COG}$ & 1.87 & 0.37 & \\
\hline $\mathrm{AFF}$ & 1.82 & 0.67 & COMP & 1.86 & 0.54 & \\
\hline MEM & 1.82 & 0.49 & SOC & 1.61 & 0.72 & \\
\hline MCOG & 1.71 & 0.51 & MCOG & 1.57 & 0.42 & \\
\hline
\end{tabular}

$\mathrm{MEM}=$ memory, COG-cognitive, COMP-compensation, $\mathrm{MCOG}=$ metacognitive, AFF-affective, SOC=social

The second research question seeks to analyze the influence of age on learning strategies. The total numbers of students were divided into two groups, young adults ( $<25$ years) and older adults $(>25$ years). As shown in table 4 , both the groups displayed low strategy use. The younger adults indicated a higher usage of compensation and social strategies, whereas the older adults demonstrated a tendency to use memory and affective strategies.

The results of the unpaired t test were used to analyze the mean differences on the basis of age distribution. The results of the test indicate that there is no difference in the mean scores between the young adults and the older adults in their strategy use. The test proved to be insignificant at $t=0.393, p=0.34$ at $n 1$ $+\mathrm{n} 2-2=80$ degrees of freedom, thus rejecting our research hypothesis that there is a difference in the scores among samples on the basis of age distribution.

Table.5: Differences in strategy use based on gender

\begin{tabular}{|l|l|l|l|l|l|l|}
\hline \multirow{2}{*}{ Strategy } & $\mathrm{M}(\mathrm{N}=34)$ & Strategy & $\mathrm{F}(\mathrm{N}=48)$ & $\mathrm{t}$ \\
\cline { 2 - 3 } & mean & $\mathrm{sd}$ & & mean & $\mathrm{sd}$ \\
\hline COMP & 2 & 0.50 & COMP & 1.99 & 0.59 \\
\hline MEM & 1.94 & 0.43 & MEM & 1.86 & 0.53 \\
\hline AFF & 1.93 & 0.57 & COG & 1.85 & 0.52 \\
\hline COG & 1.91 & 0.38 & AFF & 1.83 & 0.67 \\
\hline SOC & 1.79 & 0.73 & SOC & 1.82 & 0.71 \\
\hline MCOG & 1.63 & 0.48 & MCOG & 1.66 & 0.50 \\
\hline
\end{tabular}

MEM=memory, COG-cognitive, COMP-compensation, $\mathrm{MCOG}=$ metacognitive, AFF-affective, SOC=social

Table 5, represents the data in response to the third research question on the strategy use between males and females. Comparing the means of both genders, it is observed that there are slight variations in employing learning strategies. Although the difference is not major, males seem to have better strategies than the females. Both genders displayed a high preference for compensation strategies and least preference for metacognitive strategies.

The results of the unpaired t test indicate that there is no difference in the mean scores between males and females in strategy use. The test proved to be insignificant at $\mathrm{t}=0.343, \mathrm{p}=0.73$ at $\mathrm{n} 1+\mathrm{n} 2-2=80$ degrees of freedom. This adheres to the findings of the previous studies. (SalimRazi 2012; Abushamis 2003; Radwan, 2011) 
Table 6: Strategy use between part-time and full-time students

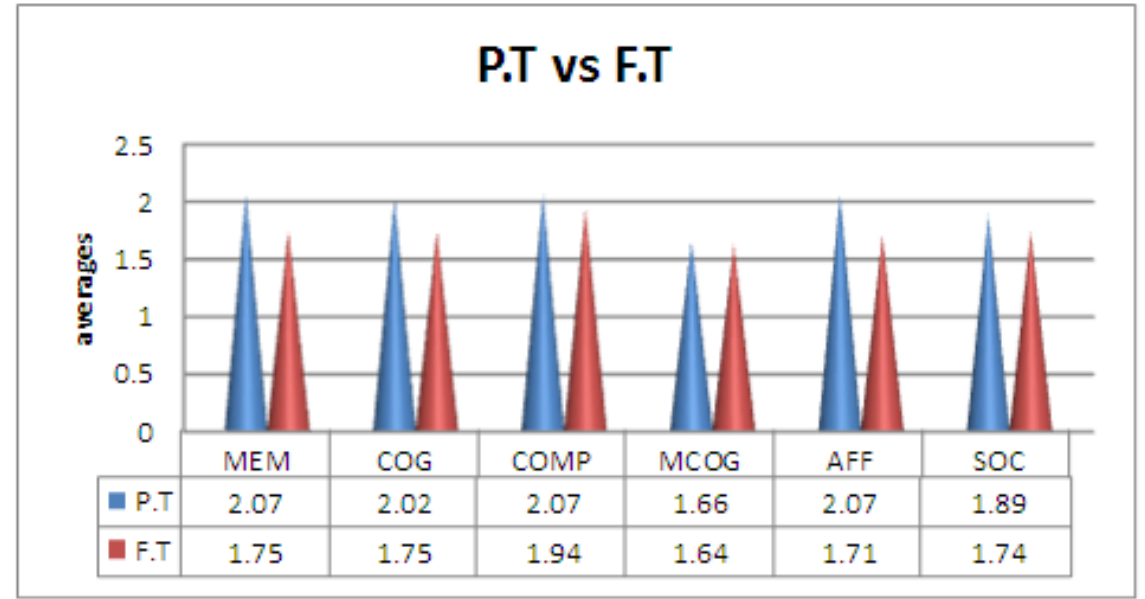

$\mathrm{MEM}=$ memory, COG-cognitive, COMP-compensation, $\mathrm{MCOG}=$ metacognitive, AFF-affective, SOC=social

The findings related to the fourth research question, "Are there differences in frequency of learning strategies between the part-time and full-time students?" are demonstrated in Table 6. In response to question 4, most of those surveyed indicated that part-time students scored consistent means in memory strategies, compensation strategies and affective strategies. The least preferred strategy common to both groups was the metacognitive strategy. The part-time students surpassed the full-time students in their strategy use.

The results of the unpaired t test specify that there is difference in the mean scores between the full time and part time students. The test proved to be significant at $\mathrm{t}=2.32, \mathrm{p}=0.011$ at $\mathrm{n} 1+\mathrm{n} 2-2=80$ degrees of freedom thus accepting our research hypothesis that there is difference in the mean scores on the basis of the mode of study.

\section{Discussions}

Several studies indicate that successful learners engage in effective strategies (Rubin 1975, Oxford 1990). The most challenging task for the instructor is to raise the level of the less proficient learners by enhancing their learning strategies. It was a pre-notion that less proficient learners would certainly display low strategy use, however, what was significant in this study was to identify what was the strategy most frequently used by the less proficient learner(see table 3) in order to improve them and plan support materials accordingly. The results pointed out that the less proficient learners employed compensation and memory strategies to substitute their lack of knowledge by guessing or inferring from various context clues or depending on their memory retention skills. According to (Oxford, 1990), 'the less proficient language learner often panics when encountered with an unfamiliar word'. Thus they resort to compensatory production strategies because they encounter language barriers. Dependency on memory strategies clearly indicates student's habit of rote learning, when they encounter complex grammar rules, which is prevalent in most educational settings.

As inferred from Table 3, Compensation strategies were the most preferred strategies by the less proficient learners. Studies that investigated students with a higher proficiency level((Alptekin, 2007; Hiçyılmaz, 2006; Karahan, 2007; Razı, 2012; Yalçın 2006; Yılmaz, 2010) reported a higher dependence on compensation strategies (as cited by Uztosun, M. S. 2014). The strategies preferred by these learners remain the same irrespective of low or high proficiency in the language. In a study carried out by Vann, R.J \& Abraham,R.G (1990), involved two unsuccessful Saudi Arabian female learners. Their findings revealed that these learners were active strategy users; however, they lacked the ability to employ the strategies appropriately. Strategies employed productively by the unsuccessful or less proficient learner can be a great resource that can be utilized by the teacher to improve the learner's performance (Rubin, 1975)

The common assumption that strategies are refined with the progression in age is to some extent based on various leaner variables in different contexts. The results of the current study prove that age does not influence the use of learning strategies which supports various studies.(Saricoban, A., \& Saricaoğlu, A. 2008;Salim Razi,2012)The younger adults are more extroverts who depend on their peers for help and adopt compensation strategies to cope up with academic requirements. The older adults, on the other hand, displayed a higher affinity towards memory and affective strategies where they memorize difficult concepts and reflect before they act. This might be because the older adults prefer the traditional way of learning by memorization or rote learning. 
The present findings seem to be consistent with other research that gender had no significance on strategy use (Abu shamis, 2003; Radwan,2011; SalimRazi 2012;Ali Erarslan,2014, Ismail, S. A. A., \& Al Khatib, A. Z. 2013)However, a similar trend was noted between the current study and Radwan(2011) that males demonstrated more strategy use than the females. This could be attributed to cultural background in Oman as remarked by Radwan (2011), where the females belong to the more conservative socio cultural domain.

The current research on the strategy use employed by the part-time students revealed that the part-time students outperformed the full-time students. It proves that various modes of study does influence learning strategies. Despite the barriers such as; the limited hours of study, full time job and college/home conflicts, it is surprising to note that part-time students have better strategies than the full-time students. The findings are in agreement with studies conducted on the academic success of nontraditional students based on their college GPA's, that non-traditional students performed better than the traditional students(Hoyt, J. E, Howell, S. L, Touchet J., Young S, \&Wygant S, 2010). The findings of Curtis and Shani(2002) also confirm that the part-time work experience has a positive impact on student performance, enhancing their skill development.

The results could be credited to the work experience of the part-time students, providing them with more exposure to the language while dealing with their colleagues at their work and other informal experiences. As cited in Oxford (1990), McBride says, 'Meaning is in fact created by the receiver in light of the experience which s/he already possesses,' Experience assists the learners in identifying the purpose of appropriate learning strategies and ,thus it is beneficial not only to the successful leaner but also the unsuccessful learner .It proves that part-time students are active strategy users, but lack guidance on how to maximize their strategic knowledge.

\section{Conclusions and Implications}

As remarked by Oxford (2003),' A given strategy is neither good nor bad; it is essentially neutral until the context of it is thoroughly considered'. The context of the learner is to be considered when planning language activities to develop appropriate strategies. As concluded from the findings regarding the strategies used by the less proficient learners, least preferred strategies were the metacognitive strategies as opposed to successful learners who scored high in metacognitive strategies (shamis, 2003; Razi 2012;Javid, C. Z., Althubaiti, T. S., \& Uthman, A. 2012). The low preference for metacognitive strategies is a predictor that the less proficient learners are unable to identify their own learning strategy or reflect upon their strengths and weakness.

Knowles (1970) maintains that people are motivated to learn only when they feel the need to cope up with real life problems. This 'need to learn' is lacking among unsuccessful learners, they have the potential but lack the initiative to improve them. On the contrary, it was apparent that the part-time students displayed a higher use of strategies than the full time students, which indicated that they have the desire or inherent motivation to learn. The present findings seem to be consistent with other research which found that nontraditional learners are highly motivated.(Bye, D., Pushkar, D., \& Conway, M. (2007).

It is recommended to assess language learning strategies at the start of a course to identify the type of strategies that students inherent when they enroll for college programmes, the results can be exploited to plan strategy instruction, keeping in mind the strengths and shortcomings of the target group. The teacher herself should be well trained to refine the learning strategies of the learners by embedding effective strategies in daily classroom activities. A strategy based training would assist the language teacher to develop learning strategies in her students. According to Cohen, A. D., \& Weaver, S. J. (1998). 'A strategy based training(SBI) is a learner centred approach to teaching that extends classroom strategy training to include both explicit and implicit integration of strategies in the course content'

From the current research, the data on the strategy use by the part-time students depicted that the more experienced learners or the part timers were better at identifying their learning strategies. The full time learners, on the other hand, lacked the working experience, except for dependency on the formal setting (college, tutors) .This calls for a more authentic and real-world experience activities or experiential learning methods to be incorporated in the curriculum, to provide the full-time students opportunities to apply what they have learned in the formal setting. On the other hand, although part-timers performed better than full-timers, they still remain low strategy users due to their low proficiency level. They are unable to reflect on their learning and identify the areas of weakness. What is required is a customized teaching and learning scheme of work to be employed by the tutors to benefit both categories of students, part- time and the full-time.

However, with a small sample size, caution must be applied, as the findings might not be transferable to a larger population. A small sample was chosen due to the difficulty of obtaining full attendance from parttime students. This study set out with the aim of assessing the influence of learner variables such as age and gender on less proficient learners and the degree of strategy use between the full time and the part-time students. The findings have important implications for developing a curriculum with strategy based activities integrating real-life experience. In future investigations it might be possible to use a larger sample size including part-time 
students and focus on the effect of variables such as attitudes, motivation, and academic achievement, educational and cultural background on language learning strategies. This would produce graduates as per the requirements of the labor market thus bridging the gap between theory and practice.

\section{References}

[1]. RADWAN, A. A. (2011). EFFECTS OF L2 PROFICIENCY AND GENDER ON CHOICE OF LANGUAGE LEARNING STRATEGIES BY UNIVERSITY STUDENTS MAJORING IN ENGLISH. ASIAN EFL JOURNAL, 12(1), 115-163.

[2]. U.S. Department of Education, NCES. (2002b). Digest of Education Statistics 2001 (NCES 2002-130). Washington, DC: U.S. Government Printing Office

[3]. Blumberg, P. (2008) Developing Learner-centered teaching: A practical guide for faculty. San Francisco: Jossey-Bass.

[4]. Oxford, R.L., 1990: Language Learning Strategies: What Every Teacher Should Know. Boston: Heinle\&Heinle.

[5]. O'malley, J. M., \&Chamot, A. U. (1990). Learning strategies in second language acquisition. Cambridge University Press.

[6]. Reiss, M. A. (1981). Helping the unsuccessful language learner. The Modern Language Journal, 65(2), $121-128$.

[7]. Cohen, A. D., \& Weaver, S. J. (1998).Strategies-based instructions for second language learners. ANTHOLOGY SERIESSEAMEO REGIONAL LANGUAGE CENTRE, 1-25.

[8]. Rubin, J. (1975). What the" good language learner" can teach us. TESOL quarterly, 41-51.

[9]. Ali Erarslan.,\&DevrimHöl. (2014). A study on language learning strategies of Turkish EFL learners at a state university. Journal of Second and Multiple Language Acquisition,2(2), 1-10.

[10]. Razi, S. (2012).Turkish EFL Learners' Language Learning Strategy Employment at University Level. Journal of Theory and Practice in Education, 8(1), 94-119.

[11]. Shmais, W. A. (2003). Language learning strategy use in Palestine. TESL-EJ,7(2).

[12]. Uztosun, M. S. (2014). The impact of language learning experience on language learner strategy use in Turkish EFL context. International Journal on New Trends in Education \& their Implications, 5(1).

[13]. Knowles, M. S. (1970). The modern practice of adult education (Vol. 41). New York: New York Association Press.

[14]. Chamot, A. U. (2005). Language learning strategy instruction: Current issues and research. Annual Review of Applied Linguistics, $25,112-130$.

[15]. Vann, R. J., \& Abraham, R. G. (1990).Strategies of unsuccessful language learners. Tesol Quarterly, 24(2) 177-198.

[16]. Saricoban, A., \&Saricaoğlu, A. (2008). The effect of the relationship between learning and teaching strategies on academic achievement.Novitas-Royal, 2(2), 162-175.

[17]. Ismail, S. A. A., \& Al Khatib, A. Z. (2013).Investigating the Language Learning Strategies of Students in the Foundation Program of United Arab Emirates University. International Education Studies, 6(9), p135.

[18]. Hoyt , J. E., Howell, S. L., Touchet J., Young S., \&Wygant S. (2010). Enhancing Nontraditional Student Learning Outcomes in Higher Education. PAACE Journal of Lifelong Learning, 19, 23-27.

[19]. Curtis, S., \&Shani, N. (2002). The effect of taking paid employment during term-time on students' academic studies. Journal of Further and Higher Education, 26(2), 129-138.

[20]. Oxford, R. L. (Ed.). (2003). Language learning styles and strategies. Mouton de Gruyter.

[21]. Javid, C. Z., Al-thubaiti, T. S., \&Uthman, A. (2012).Effects of English language proficiency on the choice of language learning strategies by Saudi English-major undergraduates. English Language Teaching, 6(1), p35.

[22]. Bye, D., Pushkar, D., \& Conway, M. (2007). Motivation, interest, and positive affect in traditional and nontraditional undergraduate students. Adult education quarterly, 57(2), 141-158.

\section{Appendix}

Arabic Version of Strategy Inventory for Language Learning (SILL)

Version 7.0 (ESL/EFL)

(C) R. Oxford. 1989

\section{Background Questionnaire}

This questionnaire is designed to find out your learning strategies. Please answer the following questions. The data provided will be kept confidential. Thank you

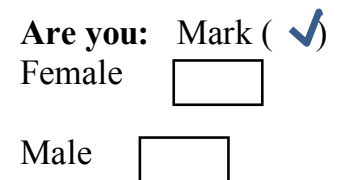

Age group:

$15-20$

$21-25$

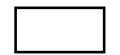

26-30

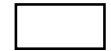

$31-35$

Are you:

a foundation student

undergraduate student

graduate student
Are you:

a full timer a part-timer 


\section{Strategy Inventory for Language Learning (SILL)}

This form of the strategy inventory for language learning (SILL) is for students of a second language (SL). Please read each statement and tick the correct response $(1,2,3,4$, or 5) that tells HOW TRUE THE STATEMENT IS. Answer in terms of how well the statement describes you. Do not answer how you think you should be, or what other people do. There is no right or wrong answers to these statements.

\begin{tabular}{|c|c|c|c|c|}
\hline ذذلك مطلقا & ذللك نادرا & 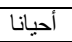 & ذللك عادة & 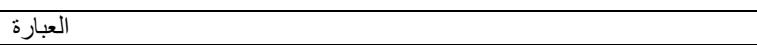 \\
\hline & & & & 1-أفكر في العلاقة بين ما أعرفه من قبل وبين الأشياء الجديدة التي أتعلمها في الإنجليزية. \\
\hline & & & & 22-أستعمل كلمات إنجليزية في جملة حتى أتمكن من تذكر ها. \\
\hline & & & & 3- أحاول أن أجد صلة ما بين صوت الكلمة الإنجليزية الجديدة وصورتها حتى أتمكن ها. \\
\hline & & & & 4-أتنكر الكلمة الجديدة عن طريق تكوين صورة ذهنية للوضع/ السياق الذي يمكن أن به. \\
\hline & & & & 5-أستخدم القافية لتنكر الكلمات الإنجليزية الجديدة. \\
\hline & & & & 6ــأستخدم البطاقات التعليمية لتنكر الكلمات الإنجليزية الجديدة. \\
\hline & & & & 7- أحاول نطق الكلمات الإنجليزية الجديدة. \\
\hline & & & & 8- أراجع الدروس الإنجليزية غالبا. \\
\hline & & & & 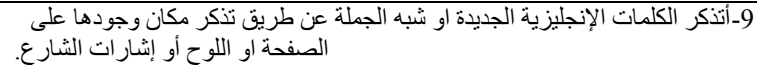 \\
\hline & & & & 10-ألفظو أكتب الكلمة الجديدة أكثر من مرة. \\
\hline & & & & 11 1-أحاول أن أنكلم الإنجليزية كالناطقين بها. \\
\hline & & & & 12 أندرب على نطق الأصو ات. \\
\hline & & & & 13-أستخدم الكلمات الإنجليزية التي أعرفها في طرق مختلفة. \\
\hline & & & & 14- أبادر في بدء المحادثة باللغة الإنجليزية. \\
\hline & & & & 15-أشاهد برامج تلفزيونية باللغة الإنجليزية أو أذهب لمشاهدة أفلام باللغة الإنجليزية. \\
\hline & & & & 16-أعمل على كتابة ملاحظات, رسائل او تقارير بالإنجليزية. \\
\hline & & & & 17-عندما أقرا أ قطعة بالإنجليزية, أققر أها أو لا بسر عة ثم أعود إليها لأقر أها بدقة وتمعن. \\
\hline & & & & 18 أقر أ الإنجليزية من أجل الإستمناع. \\
\hline & & & & 19-أبحث عن كلمات في العربية شييهة بالكلمات الإنجليزية الجديدة. \\
\hline & & & & 20-أحاول أن أبحث عن أنماط عندما أدرس بالإنجليزية. \\
\hline & & & & 21 21-أجد معنى الكلمة الجديدة عن طريق تقسيهها إلى أجز اء ليسهل فهمها. \\
\hline & & & & 22 22-أحاول أن لا أترجم حرفيا عندما أدرس. \\
\hline & & & & 23-أقوم بعمل تلخيص للمعلومات التي أقر أها أو أسمعها باللغة الإنجليزية. \\
\hline & & & & 24-أحاول أن أتحرز معنى الكلمات غير المألوفة حتى أسنطيع فههها. \\
\hline & & & & 25-أستعمل الإشارات عندما لا أستطيع أن أجد كلمة إنجليزية مناسبة خلال المحادثة. \\
\hline & & & & 26-أختلق كلمات جديدة إذا لم أكن أعرف الكلمات الإنجليزية الصحيحة. \\
\hline & & & & 27-أقرأ الإنجليزية دون أن أكتب عن معنى كل كلمة من القاموس. \\
\hline & & & & 28-أحاول أن أنحرز ما يقوله الطرف الآخر بالإنجليزية. \\
\hline & & & & 29-إن لم أجد كلمة بالإنجليزية, أستعمل كلمة أو جملة أخرى تحمل نفس المعنى. \\
\hline & & & & 30- أحاول أن أجد طرقا كثيرة من أجل أن أمارس لغتي الإنجليزية. \\
\hline & & & & 31 -أحاول أن ألحظ أخطائي التني أرتكبها من أجل أن أَّحسن أدائي. \\
\hline & & & & 32-أصغي بانتباه عندما يتحدث شخص ما باللغة الإنجليزية. \\
\hline & & & & 33-أحاول أن أبحثث عن طرق تساعدني أن أكون متعلما أفضل للغة الإنجليزية. \\
\hline & & & & 34-أرتب جدولي بحيث يكون عندي وقت كافي لدر اسة اللغة الإنجليزية. \\
\hline & & & & 35-أبحث عن أشخاص أستطيع أن أنحدث الإنجليزية معهم. \\
\hline & & & & 36-أبحثث عن فرص من أجل أن أقرأ ما أستطيع باللغة الإنجليزية. \\
\hline & & & & 37-عندي أهداف و اضحة من أجل تحسين مهارتي باللغة الإنجليزية. \\
\hline & & & & 38_أفكر بطرق تقدمي في تعلم الإنجليزية. \\
\hline & & & & 39-أحاول أن أسترخي عندما أشعر بالخوف من استعمال الإنجليزية. \\
\hline & & & & 40-أشجع نفسي على التحدث بالإنجليزية حتى عندما اكون خائفا من ارتكاب اخطاء. \\
\hline & & & & |41-أكافئ نفسي عندما يكون أدائي جيدا بالإنجليزية. \\
\hline & & & & 42-أستطيع معرفة الأوقات التّي أكون فيها منوترا و أنا الإنجليزية. \\
\hline & & & & 43-أدون أحاسيسي ومشاعري في مفكرة خاصة بتعلم اللغة الإنجليزية. \\
\hline & & & & 44-أتحدث مع الآخرين حول شعوري وأنا أتعلم الإنجليزية. \\
\hline & & & & 45-إذا لم أفهم شيئا بالإنجليزية, أسأل المتحدث أن يبطئ أو يعيد. \\
\hline & & & & 46-أطلب من الناطقين باللغة الإنجليزية أن يصححوني إذا ما أخطأت و أنا أنكلم الإنجليزية. \\
\hline & & & & 47-أمارس الإنجليزية مع زملائي الطلبة. \\
\hline & & & & 48_أطلب مساعدة من الناطقين بالإنجليزية عندما أَحتاجها. \\
\hline & & & & 49-أطرح ح أسئلة بالإنجليزية بغرض التوضيح و التحري. \\
\hline & & & & 50- أحاول أن أتعلم عن ثقافة الناطقين بالإنجليزية. \\
\hline
\end{tabular}

Thank you for your valuable time in completing this questionnaire 